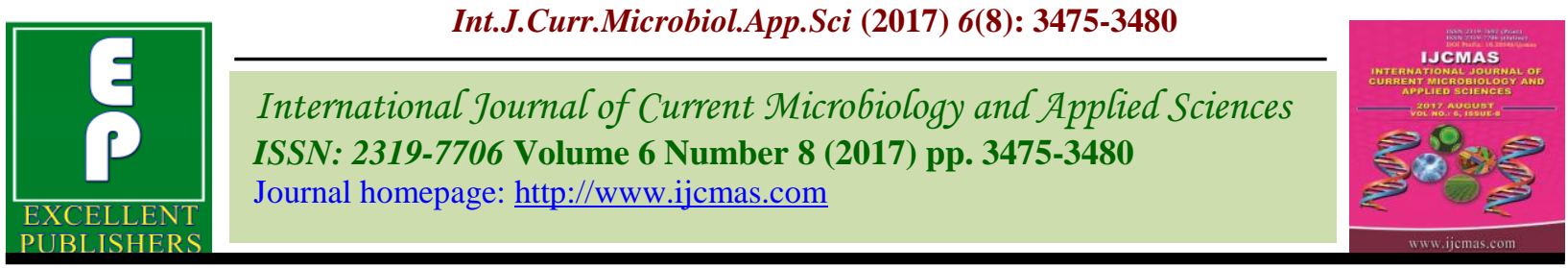

Original Research Article

https://doi.org/10.20546/ijcmas.2017.608.416

\title{
Effect of Foliar Sprays of Nitrogen, Potassium and Zinc on Flowering and Yield Attributes of Guava cv. Taiwan Pink
}

\author{
G.N. Kiran Kumar*, V. Sudha Vani, A.V.D. Dorajee Rao, \\ P. Subbaramamma and R.V. Sujatha
}

\begin{abstract}
Department of Fruit science, College of Horticulture, Venkataramannagudem, Y. S. R. Horticultural University, Andhra Pradesh, India

*Corresponding author
\end{abstract}

\section{A B S T R A C T}

\begin{tabular}{|l|}
\hline Ke y w or d s \\
Guava, Taiwan \\
$\begin{array}{l}\text { Pink, Urea, } \\
\text { Potassium } \\
\text { sulphate, Zinc } \\
\text { Sulphate. }\end{array}$ \\
\hline Article Info \\
\hline $\begin{array}{l}\text { Accepted: } \\
\text { 27 June 2017 } \\
\text { Available Online: } \\
\text { 10 August } 2017\end{array}$ \\
\hline \hline
\end{tabular}

The present investigation entitled "Effect of foliar sprays of nitrogen, potassium and zinc on flowering and yield attributes of guava cv. Taiwan Pink" was carried out at Farmer's field at Manchili village near Athili with the support of Department of Post-Harvest Technology at College of Horticulture, Dr. Y.S.R. Horticultural University, Venkataramannagudem, West Godavari District of Andhra Pradesh during 2016-2017. The experiment was laid out in randomized block design with three replication and ten treatments. The results revealed that foliar spray of plant nutrients improved yield parameters over the control. The highest number of flowers per shoot (7.20), fruit set percentage $(74.88 \%)$, number of fruits per shoot (3.82), fruit yield $(16.20 \mathrm{~kg} /$ tree), fruit retention $(71.16 \%)$ and the lowest fruit drop percentage (28.84\%) and highest fruit weight $(293.33 \mathrm{~g})$, fruit volume $\left(266.66 \mathrm{~cm}^{3}\right)$, fruit length $(8.40 \mathrm{~cm})$ and fruit girth $(8.67 \mathrm{~cm})$ were recorded in plants sprayed with nitrogen in the form of urea @ 3\% followed by plants sprayed with nitrogen in the form of urea @ $4 \%$.

\section{Introduction}

Guava (Psidium guajava L.) belongs to the family Myrtaceae, popularly known as 'Apple of the Tropics' is one of the widely grown fruits of India. It is the fourth most important fruit crop in both area and production after mango, banana and citrus. Presently, it is widely grown all over the tropics and subtropics upto 1500 meters above mean sea level. It is originated in Tropical America and presently Mexico, Peru, Brazil, India, Thailand, USA (Hawaii), Philippines, China, Indonesia, Cuba, Java, Venezuela and Bangladesh are the leading commercial producers of guava. Guava has gained considerable prominence on account of its high nutritive and medicinal values and also aroma and flavour. It is a rich source of vitamin $\mathrm{C}$, pectin, moderately good source of iron, calcium and a fair source of phosphorus, besides very rich sources of dietary fiber. In India, guava is cultivated in an area of about 2.68 lakh ha with a production of 36.67 lakh tonnes and productivity of $13.7 \mathrm{MT} / \mathrm{ha}$ (NHB, 2015). Application of fertilizers through soil are needed in higher quantities because some amount of fertilizers are lost through leaching 
and some amount of fertilizers become unavailable to the plants due to complex chemical reactions. Therefore, foliar application of nutrients through foliage is an alternative way in fruit crops. Moreover, plants require micronutrients in small quantities and thus, can be applied more safely and easily through foliage, which offers the possibility of quick absorption and supply the specific nutrients in a precise concentration directly to the foliage and to the fruits at times when rapid responses are desired. The major nutrients like nitrogen, phosphorus and potassium play a vital role in promotion of the plant vigour and productivity. Micronutrient like zinc, boron, copper and molybdenum perform a specific role in plant growth and development and also helps in production of the quality produce. Nutrient requirement of guava vary with the varieties and agro climatic conditions. The application of both macro and micronutrients are essential to avoid the hidden nutrient hunger and to promote the optimum growth and performance in guava crop. Investigations have shown that the application of urea, potassium and zinc nutrients are important for growth, flowering, fruiting and for getting quality of fruits.

\section{Materials and Methods}

An investigation was carried out on in Farmer's field at Manchili village near Athili with the support of Department of PostHarvest Technology at College of Horticulture, Dr. Y.S.R. Horticultural University, Venkataramannagudem, West Godavari District of Andhra Pradesh during 2016-2017. The experiment was laid out in randomized block design with three replications and ten treatments viz., comprising of foliar sprays of nitrogen in the form of urea @ 2\%,3\% and 4\%,potassium in the form of potassium sulphate @ 1\%,2\% and $3 \%$ and zinc in the form of zinc sulphate
@ $0.2 \%, 0.4 \%$ and $0.6 \%$ and control respectively. First spray of different concentrations of plant nutrients was sprayed after the emergence of first flesh after pruning and second spray at 15 days after the first spray. The chemicals were properly dissolved in water before spray. Four branches per plant were randomly selected and tagged in each treatment and in each replication. The fruits were harvested based on their maturity indices viz., change in colour of fruit from dark green to yellowish green. Observations were recorded and statistically analyzed as per the methods given by Panse and Sukhatme (1967).

\section{Results and Discussion}

In the present investigation, all treatments of plant nutrients significantly increased the fruit set and yield attributes of guava as compared to control (Table 1). Highest number of flowers per shoot (7.20) was recorded in $T_{2}$ (plants sprayed with nitrogen in the form of urea @ $3 \%$ ) followed by $\mathrm{T}_{3}$ (plants sprayed with nitrogen in the form of urea @ $4 \%$ ) (6.90). The highest number of flowers per shoot recorded in plants sprayed with different concentrations of urea might be due to significant increase in number of shoots per plant with floral meristems and ultimately ended with an individual flower. The increase in number of flowers per shoot in present study was in agreement with the results obtained by Parmar et al., (2014) and Giriraj and Kacha (2014) in guava. Number of flowers per shoot was increased with an increase in concentration of urea up to $3.0 \%$ but it decreased with foliar spray of $4 \%$ urea. It indicated that increased use of nitrogenous fertilizers in the form of urea beyond $3 \%$ promotes vegetative growth and decreased the reproductive growth. These results are in corroboration with the earlier findings of the Musavi et al., (2002) in tomato. Significantly the highest fruit set $(74.88 \%)$ was recorded in 
$\mathrm{T}_{2}$ (plants sprayed with nitrogen in the form of urea @ $3 \%)$ followed by $\mathrm{T}_{3}(70.16 \%)$ plants sprayed with nitrogen in the form of urea @ $4.0 \%$. This might be due to the profuse flowering. The increase in fruit set was either by improving the germination of pollen grains or by improving the pollen tube growth thus facilitating timely fertilization before the stigma loses its receptivity or style becomes nonfunctional (Doraipandian and Shanmugavelu, 1972). Foliar sprays of urea also accelerated the arginine biosynthesis pathway, there by elevating the production of polyamines necessary for fruit set and growth (Sagee and Lovatt, 1988). The present findings are in agreement with Giriraj and Kacha (2014), Parmer et al., (2014) in guava and Sharma (2016) in apple.

The highest number of fruits per shoot (3.82) was recorded in $\mathrm{T}_{2}$ (plants sprayed with nitrogen in the form of urea @ $3.0 \%$ ) followed by $\mathrm{T}_{3}$ (3.22) plants sprayed with nitrogen in the form of urea @ $4.0 \%$ which could be due to more number of flowers per shoot and fruit set percentage. Significantly the highest fruit yield per tree (16.20) was recorded in $\mathrm{T}_{2}$ (plants sprayed with nitrogen in the form of urea @ $3.0 \%$ ) followed by $\mathrm{T}_{3}$ (15.03) plants sprayed with nitrogen in the form of urea @ $4.0 \%$. Nitrogen is an important constituent of protoplasm and was helpful in chlorophyll formation there by increasing the photosynthetic activity of guava leaves. The photo assimilates were translocated to the shoots, which resulted in an increase in number of flowers per shoot, fruit set percentage, number of fruits per shoot and reduction of fruit drop which leads to higher fruit yield per tree. Similar results were reported by the Singh et al., (2002) in grapes and Giriraj and Kacha (2014) in guava.

The highest fruit retention $(71.16 \%)$ and minimum fruit drop $(28.84 \%)$ was recorded in $\mathrm{T}_{2}$ (plants sprayed with nitrogen in the form of urea@3.0\%). which might be due to involvement of urea in the synthesis of endogenous auxins which prevents the abscission and facilitates the ovary to remain attached with the shoot and thus resulted in lower fruit drop. Similar results were reported by Syamal et al., (2008) in Kagzi lime and Giriraj and Kacha (2014) in guava.

Significant variation (Table 2) was recorded among different treatments on fruit parameters. The maximum fruit weight $(293.33 \mathrm{~g})$ and fruit volume $\left(266.66 \mathrm{~cm}^{3}\right)$ was recorded in $\mathrm{T}_{2}$ (plants sprayed with nitrogen in the form of urea @ 3.0\%) followed by $\mathrm{T}_{3}$ (plants sprayed with nitrogen in the form of urea @ 4.0\%)(286.77 g and $258.33 \mathrm{~cm}^{3}$ respectively). An increase in fruit weight was observed in fruits harvested from the plants sprayed with urea due to an accumulation of sugars and higher pulp percentage of fruits. Similar results were also reported by Singh and Rajput (1977) in guava. Increase in fruit volume with different concentrations of urea could be due to the involvement of urea in the synthesis of endogenous auxins, which results in an increase in cell division and cell elongation in fruits and also due to an increase in the accumulation of food material in the fruit cells which results in an increase in the volume of fruits. Similar results were reported by Kaur and Dhillon (2006) and Giriraj and Kacha (2014) in guava.

The maximum fruit length $(8.40 \mathrm{~cm})$ was recorded in $\mathrm{T}_{2}$ (plants sprayed with nitrogen in the form of urea @ 3.0\%) followed by $\mathrm{T}_{3}$ $(8.14 \mathrm{~cm})$ (plants sprayed with nitrogen in the form of urea@4.0\%) and highest fruit girth was recorded in $\mathrm{T}_{2}(8.67 \mathrm{~cm})$ (plants sprayed with nitrogen in the form of urea @ 3.0\%) followed by $\mathrm{T}_{3}(8.40 \mathrm{~cm})$ (plants sprayed with nitrogen in the form of urea @ 4.0\%). This might be due to accelerated rate of cell enlargement and formation of larger intercellular spaces during later part of fruit growth and also increase in either flesh or seeds or both. 


\begin{tabular}{|c|c|c|c|c|c|c|}
\hline Treatments & $\begin{array}{c}\text { Number } \\
\text { of } \\
\text { flowers } \\
\text { per shoot }\end{array}$ & $\begin{array}{c}\text { Fruit set } \\
(\%)\end{array}$ & $\begin{array}{c}\text { Number } \\
\text { of fruits } \\
\text { per shoot }\end{array}$ & $\begin{array}{c}\text { Fruit } \\
\text { yield } \\
\text { (kg/tree) }\end{array}$ & $\begin{array}{c}\text { Fruit } \\
\text { retention } \\
(\%)\end{array}$ & $\begin{array}{c}\text { Fruit drop } \\
(\%)\end{array}$ \\
\hline $\mathrm{T}_{1}$ : Plants sprayed with Nitrogen in the form of Urea @ $2.0 \%$ & 6.20 & $68.84(56.10)$ & 2.77 & 14.02 & $64.69(53.53)$ & $35.31(36.44)$ \\
\hline $\mathrm{T}_{2}$ : Plants sprayed with Nitrogen in the form of Urea @ $3.0 \%$ & 7.20 & $74.88(60.16)$ & 3.82 & 16.20 & $71.16(57.50)$ & $28.84(32.44)$ \\
\hline $\mathrm{T}_{3}$ : Plants sprayed with Nitrogen in the form of Urea @ $4.0 \%$ & 6.90 & $70.16(56.98)$ & 3.22 & 15.03 & $67.01(54.92)$ & $32.99(35.02)$ \\
\hline $\mathrm{T}_{4}$ : Plants sprayed with Potassium in the form of Potassium sulphate @ $1.0 \%$ & 5.71 & $63.11(52.63)$ & 2.12 & 12.42 & $60.09(50.90)$ & $39.91(39.06)$ \\
\hline $\mathrm{T}_{5}$ : Plants sprayed with Potassium in the form of Potassium sulphate @ $2.0 \%$ & 5.97 & $64.30(53.39)$ & 2.30 & 12.97 & $60.72(51.19)$ & $39.28(38.77)$ \\
\hline $\mathrm{T}_{6}$ : Plants sprayed with Potassium in the form of Potassium sulphate @ $3.0 \%$ & 6.14 & $65.16(53.83)$ & 2.44 & 13.50 & $61.20(51.46)$ & $38.80(38.50)$ \\
\hline $\mathrm{T}_{7}$ : Plants sprayed with Zinc in the form of Zinc sulphate @ $0.2 \%$ & 4.65 & $53.26(46.85)$ & 1.29 & 10.80 & $51.51(45.84)$ & $48.49(44.11)$ \\
\hline $\mathrm{T}_{8}$ : Plants sprayed with Zinc in the form of Zinc sulphate @ $0.4 \%$ & 5.65 & $58.74(50.02)$ & 1.88 & 12.04 & $56.93(48.97)$ & $43.07(40.99)$ \\
\hline $\mathrm{T}_{9}$ : Plants sprayed with Zinc in the form of Zinc sulphate @ $0.6 \%$ & 5.68 & $62.70(52.34)$ & 2.07 & 12.30 & $58.26(49.74)$ & $41.74(40.21)$ \\
\hline $\mathrm{T}_{10}:$ Plants sprayed with water (control) & 4.33 & $50.83(45.45)$ & 1.04 & 8.90 & $46.96(43.18)$ & $53.04(46.77)$ \\
\hline S.E $\mathbf{m} \pm$ & 0.31 & 2.15 & $\mathbf{0 . 1 5}$ & $\mathbf{0 . 8 9}$ & 1.92 & 1.92 \\
\hline $\mathrm{CD}(\mathrm{P}=\mathbf{0 . 0 5})$ & $\mathbf{0 . 9 5}$ & 6.45 & $\mathbf{0 . 4 5}$ & 2.68 & 5.75 & 5.75 \\
\hline \multicolumn{7}{|l|}{ Note: values in '()' indicate angular transformations } \\
\hline Treatments & $\begin{array}{c}\text { Fruit } \\
\text { weight } \\
(\mathrm{g})\end{array}$ & $\begin{array}{c}\text { Fruit } \\
\text { volume } \\
\left(\mathrm{cm}^{3}\right)\end{array}$ & $\begin{array}{c}\text { Fruit } \\
\text { length } \\
(\mathrm{cm})\end{array}$ & $\begin{array}{l}\text { Fruit girth } \\
\quad(\mathrm{cm})\end{array}$ & $\begin{array}{c}\text { Seed } \\
\text { weight }(\mathrm{g})\end{array}$ & $\begin{array}{c}\text { Pulp weight } \\
\text { (g) }\end{array}$ \\
\hline $\mathrm{T}_{1}$ : Plants sprayed with Nitrogen in the form of Urea @ $2.0 \%$ & 280.34 & 250.66 & 7.73 & 7.90 & 4.50 & 275.84 \\
\hline $\mathrm{T}_{2}$ : Plants sprayed with Nitrogen in the form of Urea @ $3.0 \%$ & 293.33 & 266.66 & 8.40 & 8.67 & 3.79 & 289.54 \\
\hline $\mathrm{T}_{3}$ : Plants sprayed with Nitrogen in the form of Urea @ $4.0 \%$ & 286.77 & 258.33 & 8.14 & 8.40 & 4.38 & 282.17 \\
\hline $\mathrm{T}_{4}$ : Plants sprayed with Potassium in the form of Potassium sulphate @ $1.0 \%$ & 256.10 & 225.00 & 7.32 & 7.34 & 4.79 & 251.21 \\
\hline $\mathrm{T}_{5}$ : Plants sprayed with Potassium in the form of Potassium sulphate @ $2.0 \%$ & 264.77 & 233.33 & 7.48 & 7.45 & 4.72 & 259.94 \\
\hline $\mathrm{T}_{6}$ : Plants sprayed with Potassium in the form of Potassium sulphate @ $3.0 \%$ & 267.66 & 241.66 & 7.57 & 7.65 & 4.55 & 263.12 \\
\hline $\mathrm{T}_{7}$ : Plants sprayed with Zinc in the form of Zinc sulphate @ $0.2 \%$ & 238.53 & 198.33 & 7.16 & 7.22 & 5.31 & 233.03 \\
\hline $\mathrm{T}_{8}$ : Plants sprayed with Zinc in the form of Zinc sulphate @ $0.4 \%$ & 244.51 & 206.66 & 7.28 & 7.32 & 5.25 & 239.16 \\
\hline $\mathrm{T}_{9}$ : Plants sprayed with Zinc in the form of Zinc sulphate @ $0.6 \%$ & 255.66 & 221.66 & 7.30 & 7.46 & 5.19 & 250.48 \\
\hline $\mathrm{T}_{10}$ : Plants sprayed with water (control) & 225.40 & 181.66 & 6.33 & 6.38 & 6.17 & 218.97 \\
\hline S.E $\mathbf{m} \pm$ & 7.87 & 6.89 & 0.26 & 0.27 & $\mathbf{0 . 2 2}$ & 7.42 \\
\hline $\mathrm{CD}(\mathrm{P}=0.05)$ & 23.56 & 20.64 & 0.78 & 0.81 & 0.68 & 22.22 \\
\hline
\end{tabular}


This was primarily due to the stimulation of flesh growth in fruits. The results are in agreement with the earlier findings of Sharma et al., (1990) in Langra and Singh et al., (1991) in Amrapali varieties of mango and Giriraj and Kacha (2014) in guava.

The lowest seed weight (3.79 g) was recorded in $\mathrm{T}_{2}$ (plants sprayed with nitrogen in the form of urea @ 3.0\%) followed by $\mathrm{T}_{4}(4.38 \mathrm{~g})$ (plants sprayed with nitrogen in the form of urea @ 4.0\%) might be due to an increase in pulp content by an increase in accumulation of starch in the inter cellular spaces of fruit cells which results in decrease in the number of seeds per fruit. The results are in close conformity with the findings of Agnihotri et al., (2013) in guava. Highest pulp weight $\left(289.54 \mathrm{~g}\right.$ ) was recorded in $\mathrm{T}_{2}$ (plants sprayed with nitrogen in the form of urea @ 3.0\%) followed by $\mathrm{T}_{3}(282.17 \mathrm{~g})$ (plants sprayed with nitrogen in the form of urea @ 4.0\%) The increment in fruit pulp weight might be due to an increase in cell number and cell size by nutrient elements. Similar results were reported by Khayyat et al., (2007) in date palm, Giriraj and Kacha (2014) in guava.

From the present investigation it is revealed that foliar application is an instant effective way of application of nutrients. Plants sprayed with nitrogen in the form of urea @ 3.0\% significantly increased fruit set and yield parameters of guava.

\section{References}

Agnihotri, A., Rajesh, T. and Singh, O. P. 2013. Effect of crop regulators on growth, yield and quality of guava. Annals of Plant Soil Research.15 (1): 54-57.

Doraipandian, A., and Shahmugavelu, K.G. 1972. Effect of foliar spray of urea on the yield of guava (Psidium guajava $\mathrm{L}$.) South Indian Horticulture. 20(1-4):80-1
Giriraj Jat, and Kacha, H.L. 2014. Response of guava to foliar application of urea and zinc on fruit set, yield and quality. Journal of agrisearch. 1 (2):86-91.

Kaur, G., and Dhillon, W.S. 2006. Effect of foliar application of chemicals on physico and chemical characters of variety Allahabad Safeda of guava during winter. Journal of research Punjab Agricultural University. 43(2):114-16.

Khayyat, M., Tafazoli, E., Eshghi, S. and Rajaee, S. 2007. Effect of nitrogen, boron, potassium and zinc sprays on yield and fruit quality of date Palm. American-Eurasian Journal of Agricultural \& Environmental Sciences. 2 (3): 289-296.

Marschner, H., 1995. Mineral Nutrition in Higher Plants. Academic Press, New York. Pp-299-312.

Musavi-Shalmani, M.A., Sagheb, N., Hobbi, M.S., Teimouri, S., Khorasani, A. and Pirvali-Biranvand, N. 2002. Using 15-N isotopic method to evaluate efficiency of different levels of urea under fertilizer-drip irrigation system and its comparison with furrow irrigation in tomato plant. Journal of nuclear Sciences and Techniques. 26:44-8.

NHB, 2015. Indian horticulture data base, 2014-15. National Horticultural Board, Department of Agriculture and Cooperation, Government of India, New Delhi. pp. 79.

Panse, V.G., and Sukhatme, P. V. 1967. Statistical method of Agricultural workers, ICAR Publication. New Delhi. pp.381.

Parmar, J.M., Karetha, K.M and Rathod P.J. 2014. Effect of foliar spray of urea and zinc on growth and flowering attributes of guava cv. Bhavnagar red. Advance Research Journal of Crop Improvement. 5 (2):140-3.

Purseglove, J.W., 1974. Tropical Crops 
Dicotyledons. Longman, London. Pp.208-210.

Sagee, G., and Lavatt, C.J. 1988. Nitrogen metabolism during ovary development of Citrus sinensis cv. Navel. Report of the fruit tree Research Station, University of California, Riverside. Pp29-30.

Sharma, L.K., 2016. Effect of nutrient sprays on growth, yield and fruit quality of apple under cold desert condition of Himachal Pradesh. Journal of Applied and Natural Science 8 (1): 297 - 300.

Sharma, T.R., Nair, P.K.R. and Nema, M.K. 1990. Influence of foliar spray of urea, $\mathrm{KNO}_{3}$ and NAA on physical composition of mango cv. Langra. The Punjab Horticulture Journal. 30:53-6.

Singh, C., Sharma, V.P., Usha, K. and Sagar V.R. 2002. Effect of macro and micro nutrients on physico-chemical characters of grapes cv. Perlette. Indian Journal of Horticulture. 59(3): 258-60.
Singh, J.N., Rajput, C.B.S. and Prakash, S. 1991. Effect of urea spray on fruit retention and physico- chemical composition of mango (Mangifera indica L.) cv. Amrapali. Haryana Journal of Horticultural Sciences. 20:35-38.

Singh, N.P., and Rajput, C.B.S. 1977. Chemical composition of guava fruits as influenced by nitrogen application. Progressive Horticulture. 9 (2): 67-70.

Singh, R.S., and Vashistha. 1997. Effect of foliar spray of nutrients on fruit drop, yield and quality of ber cv. Seb. Haryana Journal of Horticultural Science. 26(1-2):20-4.

Syamal, M.M., Singh, S.K., Hari Lal and Singh, B.P. 2008. Effect of urea and zinc on growth, flowering, fruiting and fruit quality of Kagzi lime (Citrus aurantifolia Swingle). Environment and Ecology. 26(3):1036-38.

\section{How to cite this article:}

Kiran Kumar, G.N., V. Sudha Vani, A.V.D. Dorajee Rao, P. Subbaramamma and Sujatha, R.V. 2017. Effect of Foliar Sprays of Nitrogen, Potassium and Zinc on Flowering and Yield Attributes of Guava cv. Taiwan Pink. Int.J.Curr.Microbiol.App.Sci. 6(8): 3475-3480. doi: https://doi.org/10.20546/ijcmas.2017.608.416 